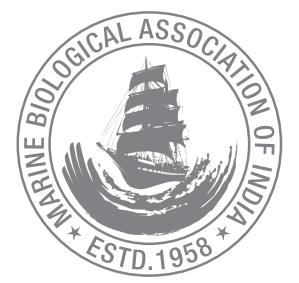

\title{
Growth performance and nutritional profile of a cyclopoid copepod Oithona similis isolated from Kochi, south west coast of India
}

\author{
Imelda-Joseph*, Boby Ignatius, Anu Mathew, V. N. Aryasree, Ashna Paul, C. N. Sarimol, \\ Shoji Joseph, Binoy Bhaskaran and Rinku Joseph \\ ICAR-Central Marine Fisheries Research Institute, Kochi- 682 018, Kerala, India.
}

*Correspondence e-mail:imeldajoseph@gmail.com

Received: 26 Aug 2019 Accepted: 02 Dec 2020 Published: 10 Dec 2020

\section{Original Article}

\begin{abstract}
A series of experiments of each 25 days were conducted to evaluate the suitability of four microalgal diets for the culture of the tropical cyclopoid copepod Oithona similis. The mono-algal diets were Chaetoceros calcitrans, Isochrysis galbana, Chlorella marina and Nannochloropsis oculata. Present work was carried out in a Completely Randomized Design (CRD) with four treatments and three replicates. After feeding 0 . similis with the 4 algal diets for 25 days, population density of adults, copepodites, nauplii and egg bearers were determined. Density and population growth rate of all stages were the maximum when fed with $C$. calcitrans and it was confirmed as an excellent diet for 0 . similis. Growth performance as indicated by population density and growth rate was significantly $(P<0.05)$ higher for all stages when fed with C. calcitrans compared to the rest of the diets. The biochemical profile of 0 . similis showed superiority in protein (55.6\%), and lipid (33.4\%) contents on feeding with $C$. calcitrans. Since the strain is cultivable with good nutritional profile and high survival rate, it gives an immense scope of high value larval feed for use in marine hatcheries. Based on the current results, it is suggested that among the diets tested, the diatom C.calcitrans was the best for enhanced production of all stages of 0 . similis in controlled conditions followed by I. galbana.
\end{abstract}

Keywords: Tropical copepods, Oithona similis, growth rate, density, nutritional profile

\section{Introduction}

The superiority of copepods as live feeds in marine fish larviculture has increased the interest towards controlled culture of copepods (Stottrup, 2003; Lee et al., 2006). Copepods are superior among live feeds due to its acceptance, digestibility and movement in the water column and a very ideal biochemical profile that meets the requirement of the most marine fish larvae (Evjemo et al., 2003; Van der Meeran et al., 2008). Nutritional quality of copepods in larviculture is determined by larval growth rate, survival, pigmentation and successful metamorphosis (Holmefijord et al., 1989; Naess et al., 1995; Naess and Lie, 1998; Shields et al., 1999). Use of copepods for marine fish larvae has reduced frequencies of skeletal deformities, improved larval pigmentation, survival and growth rate during larval and early juvenile stages (Shields et al., 1999; Payne and Rippingale, 2000; Stottrup, 2000).

For marine fish larviculture, the cyclopoid copepod Oithona sp. can be used as live feed due to its abundance, ease of 
culture and nutritional quality. The polyunsaturated fatty acids, eicosapentaenoic acid (EPA) and docosahexaenoic acid (DHA) and the calcium content in Oithona sp has been reported as higher than that in Artemia and rotifer (Chilmawatia and Sumintoa, 2016). Using Oithona as feed in larvae have shown increased level of EPA and DHA composition in Cromileptes altivelis (Valenciennes 1828) (Aliah et al., 2010), growth and survival rate of Hippocampus kuda (Chilmawatia and Sumintoa, 2016), Chanos chanos (Forsskål, 1775) (Raj et al., 2003) and Lates calcarifer (Santhanam and Perumal, 2012). O. similis is one of the most important copepod species in the world (Gallienne and Robins, 2001) and it is reflected in its abundance, biomass and trophic role within the aquatic ecosystem (Fransz and González, 1995; Metz, 1996; Atkinson and Sinclair, 2000). During its whole life span, Oithona similis Clauss, 1866 is an important predator as well as an important prey organism. In contrast to the nauplii of many other copepod species, the ones of Oithona spp. start to feed immediately after hatching (Uchima and Hirano, 1986; Hirst and Ward, 2008). There is still only very little information on mass culture of Oithona sp. as live feeds in marine larviculture. It has been reported that there are still no ideal phytoplankton diets to culture Oithona sp. in mass condition (Santhanam and Perumal, 2012; Vasudevan et al., 2013).

The present study has evaluated the egg, nauplii and copepodites production and adult population growth of the cyclopoid copepod Oithona similis fed with monocultures of micro algae namely Isochrysis galbana, Cheatocerous calcitrans, Nannochloropsis oculata and Chlorella marina.

\section{Material and methods}

The experiment was conducted at the experimental marine hatchery of Central Marine Fisheries Research Institute (CMFRI), Kochi, Kerala, India following a Completely Random Design (CRD) with four treatments spanning 25 days for each treatment. The treatments were culture of Oithona similis fed with phytoplankters (i) I. galbana; (ii) C. calcitrans (iii) N. oculata and (iv) C. marina.

\section{Phytoplankton culture}

The phytoplankton C. calcitrans (Ehrenberg, 1844), N. oculata (Droop) (Hibberd, 1981), C. marina and I. galbana (Parker, 1949) chosen to feed 0 .similis were sourced from the Microalgal Culture collection at Central Marine Fisheries Research Institute (CMFRI), Kochi, Kerala, India. The algal species were cultured at $25 \pm 1{ }^{\circ} \mathrm{C}$ in $1-20 \mathrm{~L}$ glass containers using $\mathrm{f} / 2$ medium (Guillard and Ryther, 1962) in seawater of salinity $30 \mathrm{ppt}$. and $\mathrm{pH}$ 8.2. Silicate was supplemented for the culture of the diatom C. calcitrans. The photoperiod was set at light: dark cycle of 12 $\mathrm{h}: 12 \mathrm{~h}$. Microalgae in the exponential growth phase was used to feed 0 . similis because of the high nutrient content in that stage (Creswell, 2010). The density of microalgae (Nos. $\mathrm{mL}^{-1}$ ) was calculated each day by taking a sample and counting under a microscope using haemocytometer (Improved Neaubouer volume $0.0025 \mathrm{~mm}^{3}$ ).

\section{Experimental setup}

Four separate experiments were carried out to assess the influence of the four microalgae on 0 . similis culture productivity, i.e. the population density of adult and egg bearers, production of egg, nauplii, and copepodites over a 25 day culture period. Three replicates were maintained for each treatment.

\section{Oithona similis culture}

0 . similis used for the present study was isolated from the wild and stock cultures were maintained in $1000 \mathrm{ml}$ glass containers in CMFRI laboratory. Culture of 0 . similis for experiments was done for 25 days in $3 \mathrm{~L}$ glass containers filled with sterilized seawater of salinity $30 \mathrm{ppt}$ and $\mathrm{pH} 8.5$. Initial density was 1 individual $\mathrm{mL}^{-1}$ and consisted of all stages of 0 . similis. The feeding was done once in a day using 1-2 $\times 10^{6}$ cells $\mathrm{mL}^{-1}$ of phytoplankton. Every $5^{\text {th }}$ day, the culture water was fully changed by filtering the culture through a series of sieves of mesh size 500, 200 and $60 \mu \mathrm{m}$. The sieves of varying mesh size were used to collect the different stages of the copepod. The stages were examined and counted under light microscope (10X) using Sedgwick -Rafter zooplankton counting chamber.

The population density of adult and egg bearing copepods was determined by following Camus and Zeng (2008 \& 2009). 0 . similis were acclimatized to all four diets for 3 days in $3 \mathrm{~L}$ flasks before being used for the experiment. After acclimatization period, fifty 0 . similis adults were introduced into each $1 \mathrm{~L}$ flask, for recording the population growth. Three replicates were kept for each treatment. Next 25 days, 0 . similis were fed daily with the designated diets (I. galbana; $C$. calcitrans, N. oculata, and C.marina) at a cell density of $1 \times 10^{5}$ cells $\mathrm{mL}^{-1}$ and approximately $50 \%$ of the culture water was exchanged daily by gently siphoning through a sieve. Population growth was determined on day 5 , day 10 , day 15, day 20 and day 25 .

For estimating nauplii and copepodite production, 50 adults of 0 . similis were randomly selected from the $3 \mathrm{~L}$ cultures and transferred into 12 one litre flasks and fed with the 4 experimental diets (3 replicates/ treatment). Nauplii and copepodites numbers were estimated for each microalgal diet by counting using a Sedgwick rafter cell counter and compound microscope at every 5 days intervals for 25 days. Average value of three subsamples $(5 \mathrm{~mL}$ to $10 \mathrm{~mL}$ ) taken from the each treatment was used to calculate the population growth rate $(r)$ and density of various developmental stages of 0 . similis. 
Population growth rate $(r)$ was calculated using the data obtained for each treatment by following Krebs (1985) formula as reported by Cheng et al. (2011)

$$
\mathrm{r}=\frac{\ln \mathrm{Nt}-\ln \mathrm{N}_{0}}{\mathrm{t}}
$$

Where, $\mathrm{t}$ is the total duration of culture in days, $\mathrm{N}_{0}$ and $\mathrm{Nt}$ are initial and the final density of $O$.similis (in $\mathrm{d} \cdot \mathrm{mL}^{-1}$ ).

Egg production was calculated by using the formula from Zamora-Terol et al. (2014) as given below:

$$
\frac{\sum \mathrm{sxe}}{\sum \mathrm{n}}
$$

Where, $\mathrm{s}$ is egg sac; e is average number of egg in one sac; and $\mathrm{n}$ is number of ovigerous female (ind).

\section{Biochemical analyses}

Mass culture of $O$. similis was carried out for biochemical analyses using the microalgal diets which gave better growth in previous experiments. The diets used were $C$. calcitrans, I. galbana and $N$. occulata. Cultures of $O$. similis in triplicate was maintained in 500 L FRP tanks provided with continuous aeration for 25 days. The copepod was fed with the algal diets at the rate of $1 \times 10^{5} \mathrm{cells} \mathrm{ml}^{-1}$. For biochemical analyses, the cultures which contained all the stages of $O$. similis were filtered and excess moisture was removed using absorbent paper and was dried in a hot air oven at a temperature of $60^{\circ} \mathrm{C}$ to obtain constant weight. The dried triplicate samples were pooled together for analyses. Protein content was determined by following Lowry's method with bovine serum albumin (BSA) as standard (Lowry et al., 1951). The phenol- sulphuric acid method of Dubois (Dubois et al., 1956) was followed to estimate the carbohydrate content in the copepod sample and Bligh and dyer method (Bligh and Dyer., 1959) for estimation of total lipid.

\section{Statistical analyses}

Data were analysed using one-way ANOVA and whenever significant differences $(p<0.05)$ were recorded, Tukey's multiple comparisons test was used to determine specific differences among treatments $(p<0.05)$. All statistical analyses were conducted using SPSS program Ver. 16. Data are presented as mean \pm standard deviation (SD).

\section{Results and discussion}

The copepod Oithona similis fed with four mono algal diets for a period of 25 days was examined and growth in number

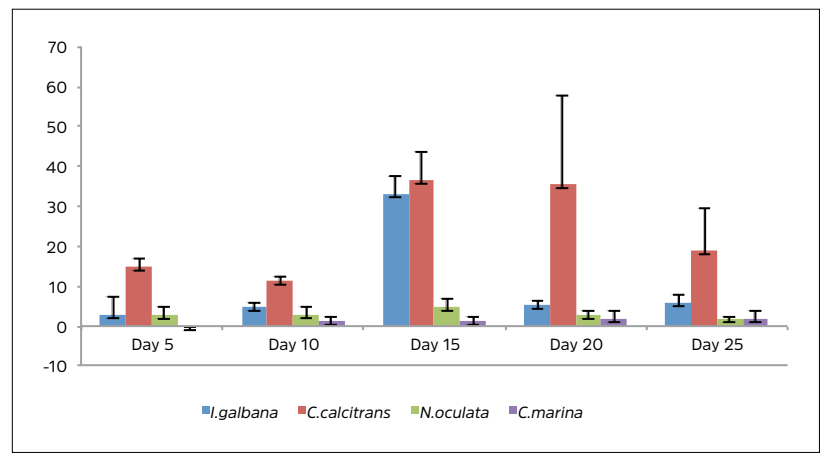

Fig. 1. Density of nauplii (ind. $\mathrm{mL}^{-1}$ ) in Oithona similis culture fed with different algal diets

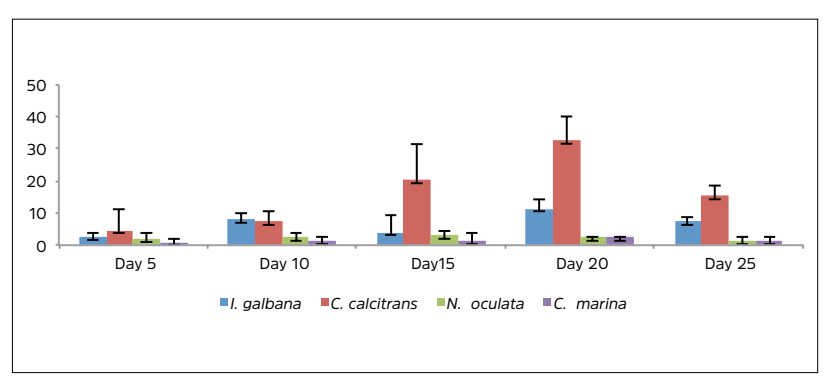

Fig. 2. Density of copepodites (ind. $\mathrm{mL}^{-1}$ ) in Oithona similis culture fed with different algal diets

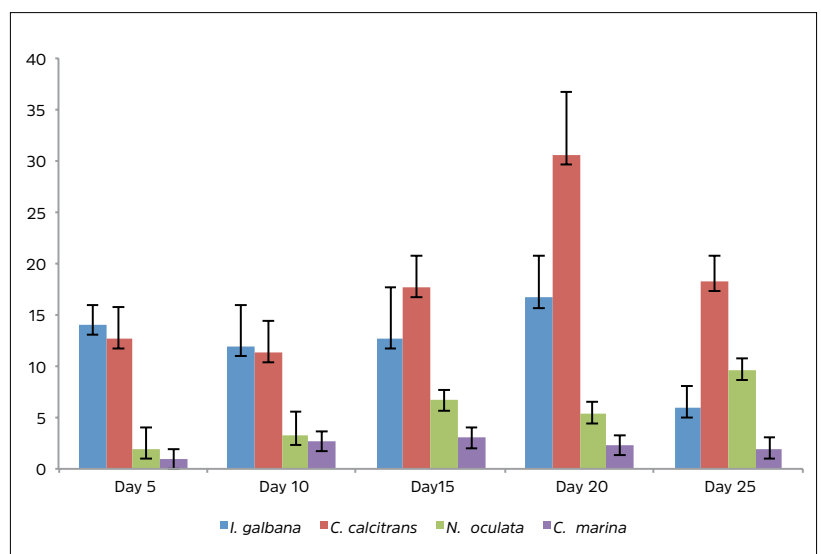

Fig. 3. Density of adults (ind. $\mathrm{mL}^{-1}$ ) in Oithona similis culture fed with different algal diets

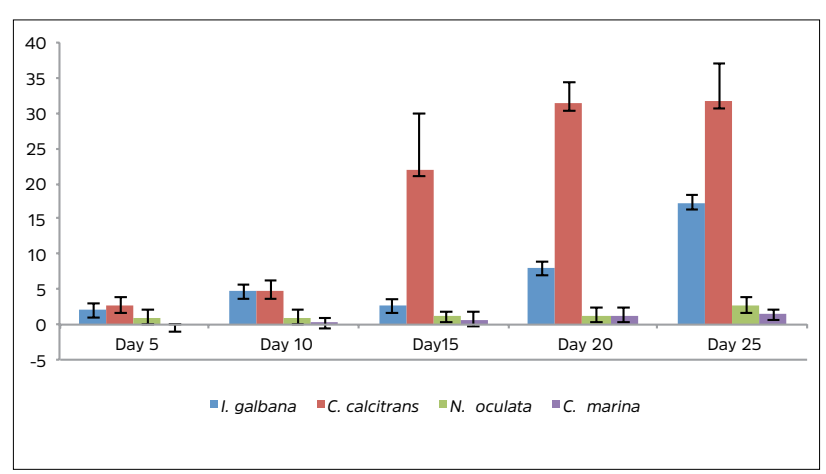

Fig. 4. Density of egg bearers (ind. $\mathrm{mL}^{-1}$ ) in Oithona similis culture fed with different algal diets 
Table 1. Population growth rate of different stages of 0 . similis in 25 days culture fed on different phytoplankton

\begin{tabular}{llllll}
\hline SI. No Diets & Adult $\left(\mathrm{d}^{-1}\right)$ & Egg producers $\left(\mathrm{d}^{-1}\right)$ & Nauplii $\left(\mathrm{d}^{-1}\right)$ & Copepodite $^{\left(\mathrm{d}^{-1}\right)}$ \\
\hline 1 & I. galbana & $0.0916 \pm 0.01$ & $0.1141 \pm 0.03$ & $0.117 \pm 0.01$ & $0.0796 \pm 0.03$ \\
\hline 2 & C. calcitrans & $0.1163 \pm 0.03$ & $0.1382 \pm 0.02$ & $0.118 \pm 0.04$ & $0.1091 \pm 0.01$ \\
\hline 3 & N. oculata & $0.0647 \pm 0.01$ & $0.1013 \pm 0.03$ & $0.088 \pm 0.01$ & $0.0114 \pm 0.01$ \\
\hline 4 & C. marina & $0.0602 \pm 0.01$ & $0.0207 \pm 0.01$ & $0.088 \pm 0.03$ & $0.0114 \pm 0.03$ \\
\hline
\end{tabular}

Table 2. Density of Oithona similis in $25 \mathrm{~d}$ culture by feeding with different algal diets

\begin{tabular}{llllll}
\hline SI. No Diets & Adult (ind $\left.\cdot \mathrm{mL}^{-1}\right)$ & Egg producers (ind $\cdot \mathrm{mL}^{-1}$ ) & Nauplii (ind $\cdot \mathrm{mL}^{-1}$ ) & Copepodite (ind $\cdot \mathrm{mL}^{-1}$ ) \\
\hline 1 & I. galbana & $6 \pm 2 \mathrm{~b}$ & $17.33 \pm 6.11 \mathrm{a}$ & $6 \pm 2 \mathrm{a}$ & $7.33 \pm 1.15 \mathrm{a}$ \\
\hline 2 & C. calcitrans & $18.33 \pm 2.51 \mathrm{a}$ & $31.66 \pm 5.50 \mathrm{a}$ & $19 \pm 10.53 \mathrm{a}$ & $15.33 \pm 3.05 \mathrm{a}$ \\
\hline 3 & N. oculata & $9.66 \pm 1.15 \mathrm{a}$ & $2.66 \pm 1.15 \mathrm{~b}$ & $2 \pm 0 \mathrm{~b}$ & $1.33 \pm 1.15 \mathrm{~b}$ \\
\hline 4 & C. marina & $2 \pm 0 \mathrm{~b}$ & $1.66 \pm 0.57 \mathrm{~b}$ & $2 \pm 2 \mathrm{~b}$ & $1.33 \pm 1.15 \mathrm{~b}$ \\
\hline
\end{tabular}

Values (Mean \pm S.D) within a column with different superscript letters were highly significant $(P<0.05)$.

was analyzed. Result of the study indicated that feed play a significant role in the population growth of cultured copepods. Growth was analyzed on day 5, day 10, day 15, day 20 and day 25 and is presented in Figures 1, 2, 3 and 4.

The different phytoplankton diets gave a different effect on growth performance of 0 . similis. Population growth rate of all four stages viz. nauplii, copepodite, adult and egg bearers of $O$. similis in 25 days fed on different phytoplankton is given in Table 1. Among treatments, 0 . similis fed with $C$. calcitrans recorded with the maximum population growth rate for all stages followed by I. galbana and N. oculata. O.similis fed with C. marina had been recorded with the lowest density with respect to number of adult copepods and growth (Table 2). In the density analysis of $O$. similis the highest average composition for all stages was observed in $O$. similis fed with $C$. calcitrans, followed by I. galbana, N. oculata and C. marina respectively. The maximum density of nauplii and copepodites were recorded in treatment using C. calcitrans as feed and the minimum was in C. marina. The maximum density of egg bearers was also obtained in cultures on feeding C. calcitrans (Table 2; Fig. 1, 2, 3 \& 4). The details of egg production of Oithona similis in $20 \mathrm{~d}$ by feeding on different algal diets are given in Table 3. Similar the case with density and growth, the maximum egg production was recorded on feeding with I. galbana and C. calcitrans.

The favorable result on population density, growth and egg production of Oithona similis was obtained in $C$. calcitrans at a temperature range of $26-30^{\circ} \mathrm{C}$, salinity $30 \mathrm{ppt}$ and food concentration of $1 \times 10^{5}$ cells $\mathrm{ml}^{-1}$. Maximum density was found by using $C$. calcitrans as feed and it was significantly higher $(p<0.05)$ from other treatments which showed lower density (Table 2).

The biochemical analyses of $O$. simils fed on different micro algal diets in mass culture was carried out and was calculated in dry matter percentage. With all diets the protein composition was $>50 \%$, lipid $>30 \%$ and carbohydrate $<10 \%$. For 0 . similis fed with $C$. calcitrans the biochemical composition estimated was protein $55.6 \%$, lipid $33.4 \%$ and carbohydrate $8.15 \%$. For O. similis fed with I. galbana the protein content $51.6 \%$, total lipid $32 \%$ and carbohydrate content $7.3 \%$. While, feeding with N. oculata, the protein content was $45.74 \%$, total lipid $29 \%$, and carbohydrate $7.3 \%$. Significant variation in nutrient composition while using $C$. calcitrans as feed revealed the fact that among the different algal diets provided, C. calcitrans and I. galbana as possible diets for $O$. similis in mass culture.

In the present study we have used four algal strains at the rate of $1 \times 10^{5}$ cells $\mathrm{mL}^{-1}$ for culturing 0 . similis under controlled conditions to identify the best diet for the growth and production. The best growth performance for 0 .similis was obtained in cultures using $C$. calcitrans as feed followed by $I$. galbana. It has been reported that $C$. calcitrans has a rich calcium content of $0.59 \%$ and phosphate content of $0.57 \%$ in the cells (Lee et al., 2006; Puelo-Cruz et al., 2009). Mineral content in the diet is important for growth and reproduction of all copepods including 0 . similis and diatoms have always been considered as a suitable source of nutrients for zooplankton to sustain secondary production in terms of reproduction (Payne and Rippingale, 2000). $N$. oculata has not been reported as feed for production of $O$. similis. Most of the studies were focused on feeding Oithona sp with Chaetoceros or I. galbana. Iwasaki

Table 3. Egg production of Oithona similis in $20 \mathrm{~d}$ culture by feeding on different algal diets

\begin{tabular}{llllll}
\hline Days & 1 & 5 & 10 & 15 & 20 \\
\hline I. galbana & 14 & 14 & 18 & 26 & 26 \\
\hline C. calcitrans & 14 & 14 & 18 & 26 & 26 \\
\hline N. oculata & 14 & 10 & 10 & 18 & 18 \\
\hline C. marina & 14 & 10 & 10 & 18 & 18 \\
\hline
\end{tabular}


et al. (1977) have been estimated optimum concentrations of micro algae for Acartia clausi in a 1:1 combination of I. galbana and Monochrysis lutheri as $1 \times 10^{6} \mathrm{cells} \mathrm{ml}^{-1}$ at $15^{\circ} \mathrm{C}$ and $1.5 \times 10^{6}$ cells $\mathrm{ml}^{-1}$ at $20^{\circ} \mathrm{C}$. While feeding with Chaetoceros muelleri, the copepod Pseudodiaptomus euryhalinus had shown the best production as reported by Lee et al. (2006). Payne and Rippingale (2000) have also been reported that copepods fed by $C$. calcitrans tended to have a shorter time to maturity and produce more nauplii than those fed by Dunaliella. The present study also is in conformity with the earlier studies showing that C. calcitrans as the preferred diet for Oithona sp. (Chilmawatia and Sumintoa 2016). Based on the results obtained, it has been concluded that among the four different microalgal diets C. calcitrans, I. galbana or N.oculata can be used for mass culture of 0 .similis. However, it has been concluded that $C$. calcitrans is the most preferred diet of $O$. similis.

\section{Acknowledgements}

The authors are grateful to Dr. A. Gopalakrishnan, Director, ICAR- Central Marine Fisheries Research Institute (CMFRI), Cochin for the facilities.

\section{References}

Aliah, R. S., Kusmiyati and D. Yaniharto. 2010. Pemanfaatan Copepoda Oithona sp. Sebagai Pakan Hidup Larva Ikan Kerapu. [Application of Copepoda Oithona sp. as Live Feed for Grouper Larvae] Jurnal Sains dan Teknologi Indonesia, 12(1): 45-52. [Bahasa Indonesia].

Atkinson, A. and J. D. Sinclair. 2000. Zonal distribution and seasonal vertical migration of copepod assemblages in the Scotia Sea. Polar Biol., 23: 46-58.

Bligh, E.G. and W.J.Dyer. 1959. A rapid method for total lipid extraction and purification. Can. J. Biochem. Physiol., 37: 911-917.

Camus, T. and C. Zeng. 2008. Effects of photoperiod on egg production and hatching success, naupliar and copepodite development, adult sex ratio and life expectancy of the tropical calanoid copepod Acartia sinjiensis. Aquaculture, 280: $220-226$.

Camus, T. and C. Zeng. 2009. The effects of stocking density on egg production and hatching success, cannibalism rate, sex ratio and population growth of the tropical calanoid copepod Acartia sinjiensis. Aquaculture, 287: 145-151.

Cheng, S. H., C. S. Kuo, S. Ka, R. Kumar and J. S. Hwang. 2011. Effects of salinity, food level, and the presence of microcrustacean zooplankters on the population dynamics of rotifer Brachionus rotundiformis. Hydrobiologia., 666:289-299.

Chilmawatia, D. and Sumintoa. 2016. The effect of different diet of phytoplankton cells on growth performance of copepod, Oithona sp. in semi-mass culture. Aquatic Procedia., 7: 39-45.

Creswell, L. 2010. Phytoplankton culture for aquaculture feed. Southern Regional Aquaculture Center. SRAC Publication No. 5004. 13 pp.

DuBois, M., K. Gilles, J. Hamilton, P. Rebers and F. Smith. 1956. Colorimetric method for determination of sugars and related substances. Anal. Chem., 28 (3): 350-356.

Evjemo, O. J., K. I. Reitan and Y. Olsen. 2003. Copepods as live food organisms in the larval rearing of halibut larvae (Hippoglossus L.) with special emphasis on the nutritional value. Aquaculture, 227(1):191-210.
Fransz, H. G. and S. R. Gonzalez. 1995. The production of Oithona similis (Copepoda: Cyclopoida) in the Southern Ocean. ICES J. Mar. Sci., 52:3-4, 549-555.

Gallienne, C. P. and D. B. Robins. 2001. Is Oithona the most important copepod in the world's oceans? J. Plankton Res., 23: 1421-1432.

Guillard, R. R. L. and J. H. Ryther. 1962. Studies on Marine Planktonic Diatoms I. Cyclotella nana Hustedt and Detonula confervacea (Cleve) Gran. Can. J. Microbiol. 8: 229-239.

Hirst, A. G. and P. Ward. 2008. Spring mortality of the cyclopoid copepod Oithona similis in polar waters. Mar. Ecol. Progr. Series., 372: 169-180.

Holmefijord, I., S. Bolla and K. I. Reitan. 1989. Start feeding of Atlantic halibut (Hippoglossus L.) on enriched rotifers and Artemia compared with collected plankton (Abstract). Rapp. Pro \& s-verb. Conseil Int. Explor. Mer., 191: 479.

Iwasaki, H., H. Katoh and T. Fujiyama. 1977. Cultivation of the marine copepod, Acartia clausi Giesbrecht: I. Factors affecting the generation time and egg production. Bull. Plankton Soc. Japan., 24: 55-61.

Krebs, C.J. 1985. Ecology. The experimental analysis of distribution and abundance. 3rd edition. Harper \& Row, New York, 592 pp.

Lee, K.W., H. G. Park, S. M. Lee and H. K. Kang. 2006. Effects of diets on the growth of the Brackishwater cyclopoid copepod Paracyclopina nana Smirnov. Aquaculture. 256: $346-353$

Lowry, O.H., N.J. Rosenberg, A. L. Fare and R. J. Randall. 1951. Protein Measurement with the Folin Phenol Reagent. J. Biol. Chem., 193:265-275.

Metz, C. 1996. Life strategies of dominant Antarctic Oithonidae (Cyclopoida, Copepoda) and Oncaeidae (Poecilostomatoida, Copepoda) in the Bellingshausen Sea. Ber. Polarforsch., 207: 123.

Naess, T., M. Germain-Henry and K. E. Naas. 1995. First feeding of Atlantic halibut (Hippoglossus hippoglossus) using different combinations of Artemia or wild zooplankton. Aquaculture., 130:235-250.

Naess, T. and O. Lie. 1998. A sensitive period during first feeding for the determination of pigmentation pattern in Atlantic halibut, Hippoglossus hippoglossus juveniles: the role of diet. Aquacult. Res., 29: 925-934.

Payne, M. F. and R. J.Rippingale. 2000. Evaluation of diets for culture of the calanoid copepod Gladioferens imparipes. Aquaculture, 187: 85-96.

Puelo-Cruz, A. C., S.Mezo-Villalobos, B.González Rodríguez and D.Voltolina. 2009. Culture of the Calanoid Copepod Pseudodiaptomus euryhalinus (Johnson 1939) with different phytoplankton diets. Aquaculture, 290:317-319.

Raj, M., A. R. T. Arasu, M. Kailasam, R. Subburaj, G.Thiagarajan and Anuradha. 2003. Studies on the relative preference of rotifer (Brachionus plicatilis), Copepod (Oithona brevicornis) and Artemia nauplii for milkfish (Chanos chanos) fry rearing. Proceedings of $3^{\text {rd }}$ interaction Workshop, Hisar, India, December 17-18, 2003, 170-172.

Santhanam, P. and P. Perumal. 2012. Evaluation of the Marine Copepod Oithona rigida Giesbrecht as live feed for larviculture of Asian Seabass Lates calcarifer Bloch with special reference to nutritional value. Indian J. Fish., 59(2):127-134.

Shields, R. J., G. Bell, F. S. Luizi, B. Gara, N. R. Bromage and J.R. Sargent. 1999. Natural copepods are superior to enriched Artemia nauplii as feed for halibut larvae (Hippoglossus hippoglossus) in terms of survival, pigmentation and retinal morphology: relation to dietary essential fatty acids, J. Nutr., 129 (6): 1186-1194.

Stottrup, J.G. 2000. The elusive copepods: their production and suitability in marine aquaculture. Aquacult. Res., 31: 703-711.

Stottrup, J. G. 2003. Production and nutritional value of copepods. In: Live feeds in marine aquaculture, Stottrup, J.G and McEvoy, L.A. (Eds.). Blackwell, Oxford, 318p.

Uchima, M. and R. Hirano. 1986. Food of Oithona davisae (Copepoda: Cyclopoida) and the effect of food concentration at first feeding on the larval growth. Bull. Plankton Soc., Japan, 33: 21-28.

Van der Meeran, T., R. E. Olsen, K. Hamre and H. J. Fyhn. 2008. Biochemical composition of copepods for evaluation of feed quality in production of juvenile marine fish. Aquaculture, 274:375-397.

Vasudevan, S., M. P. Arulmoorthy, P. Gnanamoorthy and V. A. Prabu. 2013. Intensive Cultivation of the Calanoid Copepod Oithona rigida for Mariculture Purpose. Int. J. Pharm. Biol. Sci., 3:317-323.

Zamora-Terol, S., R. Swalethorp, S. Kjellerup, E. Saiz and T. G. Nielsen. 2014 Population Dynamics and Production of the Small Copepod Oithona spp. in a Subarctic Fjord of West Greenland. Polar. Biol., 37:953-965. 